\title{
Józef Bocheński and static religion
}

\author{
Piotr Kostyło
}

Published online: 29 August 2013

(C) The Author(s) 2013. This article is published with open access at Springerlink.com

\begin{abstract}
One of the most interesting aspects of Józef Bocheński's philosophy was its relation to Henri Bergson's thought, particularly to his philosophy of religion. Unlike the majority of the Catholic philosophers at that time, Bocheński did not stress the significance of dynamic religion, but rather focused on the role of static religion in human life. In his view, what was of particular interest within this religion was its fabulation function. This direction of the philosopher's research stemmed from the realism and empiricism proper to the analytic philosophy developed by Bocheński and became increasingly visible as the years passed. In this text the author shows how Bocheński's analyses of religion, referring to both daily human experiences and logic, moved towards Bergsonian static religion, while diverging from dynamic religion and its key notion of mysticism.
\end{abstract}

Keywords Dynamic religion · Mysticism - Static religion · Fabulation function

The hypothesis that I would like to put forward in this article is as follows: Bocheński's lifelong authentic and accommodating interest in Bergsonian philosophy of religion was focused mainly on static religion; references to dynamic religion are rare in Bocheński's thought and are usually accompanied by a distinct scepticism about the possibility of coming to know and describe the phenomenon. This is very surprising since the Catholic philosophers contemporary to Bocheński who commented on Bergsonian philosophy of religion underscored therein the importance of dynamic religion, in which they saw, as did Bergson himself, the embodiment of the spirit of the Gospel. Bocheński, however, contemplating two

P. Kostyło ( $\bowtie)$

Department of Philosophy of Education, Kazimierz Wielki University, Bydgoszcz, Poland e-mail: piotr.kostylo@ukw.edu.pl 
concepts of Bergsonian philosophy of religion, spiritualism and naturalism, was unambiguously in favour of the latter. In taking this stance, Bocheński confirmed both his own originality and the status of solitary philosopher which accompanied him throughout his life.

The text that follows consists of three parts. In the introduction, I discuss the difference in the way Bocheński and Bergson practised philosophy. Although philosophers will be familiar with these differences, it seems nevertheless appropriate to begin here in order to preclude false conclusions given certain similarities in their understanding of religion. In this part, I briefly recall Bergson's basic theses concerning static and dynamic religion. In the next part, I discuss the impact of Bergson's philosophy on the young Bochenski, especially through his concept of religion as set forth in Les deux sources de la morale et de la religion. Then, in the main part of this article, I reconstruct Bocheński's key philosophical texts in which the philosopher refers in turn to static religion with its fabulation function and then to dynamic religion with mysticism remaining at its centre. I conclude with a brief summary.

\section{Introduction}

It is difficult to find two philosophers who would differ as much in their understanding of philosophy as Bocheński and Bergson. The former, as he writes himself in his Selbstdarstellung, considered himself a hard analyst with a clear predilection for subtle logical inquiry. For him, both intuition and irrationalism in philosophy were superstitions. The latter, starting with his dissertation, Essai sur les données immédiates de la conscience, consistently questioned the privileged place of the intellect in cognition, arguing that this place is in fact reserved for intuition. In all his major texts Bergson only referred to logic three times, as if in passing, saying that it is a perfect expression of what is static, the last step in the petrification of what is given directly, in short, life.

We must therefore say that despite Bochenski's sincere appreciation of Bergson's philosophy and even his conviction that it harboured genius, he was in no way a Bergsonian. In Selbstdarstellung he does not even once mention Bergson's name. In some texts, he clearly dissociated himself from the latter's philosophy, as, for example, when he favours the anthropological side of Platonism and defines the human being as "an animal capable of being perfect." He contrasts this definition with, among others, the definition of the human being as a manufacturer of tools, i.e. the Bergsonian homo faber. Elsewhere he writes: "I do not believe in something like a double truth or, even more, in the possibility of substituting logical thinking with feelings or poetic images" (Bocheński 1993a, p. xxix). This fragment also proves Bocheński's great distance from Bergsonism, more specifically from the Bergsonian philosophical method consisting, as we know, in directly experiencing reality, not in defining it. There are other such examples, though I will refrain from citing them for lack of space. Only at one point does Bocheński seem to sympathize with Bergson's approach, but on this occasion he does not refer to the French philosopher, but rather to Hegel. The question here concerns the evolutionary 
approach, thinking in terms of development, which Bocheński says is missing in Aristotle. This slight tribute to Bergson, however, does not reduce the fundamental disparities that exist between the two philosophers. Unlike Bocheński, Bergson certainly was not an analyst, rationalist, or Platonist. Although his thinking can be characterized as cosmocentric and in the beginning at least as Aristotelian, it is almost certain that the two philosophers would diverge substantially as to the importance each attributed to such concepts. ${ }^{1}$

Taking a radically different philosophical position did not prevent Bocheński from noticing the importance of Bergson's philosophy and adopting individual strands. ${ }^{2}$ The strand that Bocheński took a particular interest in was the Bergsonian philosophy of religion.

Bergson presented this philosophy in Les deux sources de la morale et de la religion of 1932. In this book, which was a surprise for many, he described two types of religion: one static, the other dynamic. These two types correspond to two types of morality: closed and open. Bergson gave a biological sense to both types of religion and morality, placing them on two divergent lines of evolution. I will not concern myself here with Bergson's understanding of evolution; for our purposes it suffices to note that at its roots lies the famous élan vital, i.e. the 'vital impetus' or 'vital force', which, according to Bergson, is the spiritual energy flowing from God. The two types of religion, like those of morality, respond to two evolutionary needs: the need to maintain the security of the group and the need for creativity.

Static religion is based on instinct, which reveals itself, in humans endowed with intelligence, in the so-called infra-intellectual emotion. Its role is to console people, to provide them with encouragement in situations of doubt and crisis, especially the crisis arising from the recognition of mortality. This comfort is provided by the images the intelligence triggers, the fabulation. These images move people beyond actual experience, convincing them that something that is permanently denied by that experience - namely life after death-is possible. This fabulation function is an essential tool of static religion. This religion is conservative, it is focused on the good of the group, having to do with order and conveying a sense of necessity. It is a religion of ants and bees toiling for their survival in a hostile world and comforting themselves with fairy tales. At the same time it is a religion of law and authority, of the Holy Scripture and the Creed. Static religion is in many ways inferior to the religion of the second type, which Bergson names dynamic religion.

Dynamic religion is the religion of saints and mystics; it is revealed in a certain emotion of a supra-intellectual nature that Bergson explicitly called love. Its source

\footnotetext{
1 The essential difference between Bergson's method and the method of Koło Krakowskie [the Kraków Circle] (of which Bocheński was a member) was noted by Jan Salamucha. According to him, in terms of methodology Bergson represented a minimalist philosophy, while the Kraków Circle represented a maximalist one (cf. Pouivet 2009, p. 240).

2 Jan Woleński notes that the Lvov-Warsaw School, with which Bocheński affiliated himself, rejected Bergson's intuitionist metaphysics (Skoczyński and Woleński 2010, p. 431). The rejection of Bergson's basic philosophical thesis did not, however, imply a negative assessment of his philosophy as a whole. Stanislaw Borzym writes about the inspirational influence of some strands of Bergson's philosophy on the Lvov-Warsaw School. He reports that many members of the Lvov-Warsaw School turned to Bergson's philosophy with "benevolent interest," despite the fact that the main tendencies of this school "failed to tally with Bergson's aspirations” (Borzym 1984, p. 248).
} 
should be sought in that direct experience, intuition, empathy with life, which is for Bergson, in the case of religion, tantamount to empathy with God. This empathy enables a unity of the will of mystics and saints with God, and as a result a continuation of the creative act, or the transformation of the world, by them. This act is accompanied by a relation to a particular person, a sense of inner calling, and a climate of complete freedom. Owing to the individuals who experience life in this way, and whom Bergson called privileged souls, moral and religious progress in societies is possible. Dynamic religion is superior to static religion; it is, so to speak, a true religion, the one that God calls us to. Bergson believes that, although it fully reveals itself only in a few people, the sparks of mysticism flicker in everyone and they can be ignited as soon as one person encounters another whom he will recognize as his master to imitate. Dynamic religion is a religion that reveals itself in the meeting of people, and not in books or in the Creed. It does not need the fabulation function since a person united in this way with life does not experience discouragement, nor does he notice the problems that pile up in front of him, or think about death with fear. It is a religion of unique personalities, supermen who were given the privilege of direct experience of God already in this world. In its essence, it is a pure emotion, impulse, and creative intuition. So much by way of introduction.

\section{Bocheński's encounter with Bergson's philosophy}

It is not clear when Bocheński encountered Bergson's philosophy for the first time. It can be assumed that it was in the years 1922-1926, while still a layman, when he studied Economics and Political Economy at the University of Poznan, under the direction of Florian Znaniecki. Znaniecki was the translator of Bergson's Evolution créatrice and, in the first philosophical period of his work, an expert and commentator on his philosophy. "Znaniecki had a simply fascinating effect on me, as on all of us," Bocheński would write later (Bocheński 1993a, p. VIII).

An important period for Bocheński's study of Bergson coincided with his studies of philosophy at Fribourg University $(\mathrm{CH})$. Bocheński met there a Brazilian priest, Maurilio Teixeira Leite Penido, who lectured on contemporary philosophy. Penido wrote his doctorate on Bergson and was, as Bocheński noted, not only a very good lecturer, but also an independent thinker. Many years later, Bocheński wrote: "I owe him quite a lot, especially when it comes to understanding Bergson" (Bocheński 1993b, p. 81). During his studies Bocheński discovered the specificity of philosophy in the twentieth century, the fact that it radically breaks with modern philosophy. "Fr. Penido's lectures, and, maybe above all, my reading and meditation on Bergson played their role in this discovery along with my becoming familiar with mathematical logic" (ibid., p. 313). We do not know what Bocheński read, but certainly not Les deux sources de le morale et de la religion, as Bergson published this book only in 1932 .

Bochenski's first comment on the Bergsonian philosophy of religion is in a letter to his father, dated May 29, 1932, and it is enthusiastic. Bocheński wrote that he was going to spend the two weeks prior to his last retreat "reading Bergson's new work, in which the great philosopher finally wrote what he thought of God." Bocheński 
called Bergson's reasoning "interesting," referring to the Bergsonian proof of God's existence. "[O]ne cannot prove the existence of God, but the most diligent study that Bergson himself carried out using a sophisticated and complex method shows that hundreds of people of first-class ability and holiness claimed to have had an experiential knowledge of God-namely mystics." Bocheński confidently stated that " $[\mathrm{t}]$ here is no scientific reason to deny their competence and veracity-on the contrary, any historical science would have to be abandoned in this case. Thus, the existence of God is probable to the highest degree" (Bocheński 2008, p. 49). Bocheński concluded that this is one more proof in support of his proposition that no great philosopher had ever denied the existence of God. Bocheński read Bergson here as the vast majority of the then contemporary Catholic thinkers did, emphasizing the importance of dynamic religion, seeing in the experience of mystics a confirmation of the existence of God.

In the same year, in the ninth issue of the monthly Droga, Bocheński, under the pseudonym of Jan Ursyn, published an article under the title "The Problem of Catholicism in Poland." In it he tackled the issue of the crisis and future of Polish Catholicism. In his analyses, more sociological than philosophical, he relied on the Bergsonian concept of static and dynamic religion, which he had recently become familiar with. He wrote: "Polish Catholicism is a static religion-at least in the form in which it is the dominant religion" (Bocheński 1932, p. 775). The religiosity of an average Polish Catholic, especially a peasant and a landowner, consists of a series of products of the "myth-creating function of homo sapiens" that have no justification in the Catholic religion; they are practices unthinkingly accepted under the pressure of social tradition. Sometimes these practices are simply superstitious in nature, which is particularly true of the former Russian partition. A significant part of the intelligentsia, which is non-Catholic and, in fact, non-believing, but is still "recorded" in the Church, remains in opposition to this mainstream Catholicism. Now, if the battle was to be fought only between "static" Catholics and the socially influential intelligentsia that is inimical to religion, the outcome of this fight would be easy to predict-static Catholicism would cease to exist. However, as Bocheński notes, there are also dynamic strands in Polish Catholicism, perhaps not as strong as in French or German Catholicism, but clear all the same. It is a matter of the emergence of Catholics of a religious sensitivity different from the traditional one. These people play a vital role in religion as "dynamic religion arises, grows and deepens through elevating individuals to a higher mystical level who then rouse the crowds" (Bocheński 1932, p. 782). Owing to them, Bocheński continues, there is a chance that large numbers of "static" Catholics will not be drawn away from religion by the non-believing intelligentsia, but will stay with religion, discovering in it a new source of vitality.

Bocheński's reference to France as a country where dynamic Catholicism is growing particularly rapidly requires some comment. As a matter of fact, the attitude of French Catholic philosophers to Bergson was complex and two attitudes can generally be distinguished here. ${ }^{3}$ The first is an attitude of overwhelming

\footnotetext{
3 More on this is explained in the text I am who I am becoming. Henri Bergson and the Problem of God, see Kostyło (2007).
} 
criticism of the letter of Bergsonian doctrine. The key thing here was the obvious incompatibility of Bergsonian and scholastic metaphysics. This attitude was represented mainly by Jacques Maritain, one of Bergson's former students who, interestingly, owed his conversion to Catholicism to Bergson. Maritain's interpretation of Bergson was taken over by the official authorities of the Church, and no doubt contributed to the inclusion of Bergson's books in the Index Librorum Prohibitorum in 1914. Such would also have been the fate of Les deux sources de la morale et de la religion had it not been for the personal intervention of Jacques Chevalier with the papal nuncio in Paris. The other approach to Bergson's philosophy favoured interpreting the spirit of that philosophy as a sincere search for truth and gradual opening to the Christian God. Antonin-Gilbert Sertillanges and Jean Guitton were representatives of this approach. The publication of Les deux sources de la morale et de la religion changed the situation to such an extent that the critics who had fundamentally rejected Bergson now began talking about him in warmer terms wherever dynamic religion was at issue. This is the meaning of, for example, a book by Penido, the priest mentioned above, entitled Dieu dans le Bergsonisme. In general, we can say that Catholic philosophers praised Bergson for developing the concept of dynamic religion in which they perceived a sign of the philosopher's spiritual proximity to Catholicism. There is a text by Maurice Blondel from 1943 which is significant in this respect, entitled Open Philosophy, in which the author distinguishes between two approaches to Christian thought. He writes that this thought is presented either as an expression of spiritual passion, generous beauty, and mystical grandeur, praising its essential truth and supreme inspiration, or as a historical reality, having a specific intellectual structure as a set of precepts and practices that make up a chain of truths to be adopted necessarily. As Blondel notes, Bergson never accepted Christian thought in the latter sense, but in the former meaning it was certainly close to him. It seems this concept has remained attractive for Catholics in the present, as demonstrated by a text published in Osservatore Romano in the mid 1990s, in which Bergson's work was described as bipolar, one pole being the subtle and obscure letter of Bergsonian philosophy, the other its inspirational quality.

Bocheński's approach to Bergson was fundamentally different. He was neither a critic of Bergson in the sense that Maritain was, nor was he his follower in the sense that Sertillanges or Guitton were. He did not distinguish between the spirit and the letter of Bergsonian philosophy. Bocheński's youthful fascination with dynamic religion after the war clearly gave way to analyses of static religion. And the part of static religion that was most interesting to Bocheński was the fabulation function.

\section{The fabulation function and static religion}

It is difficult to say when Bocheński perceived the special role of the fabulation function in Bergsonian analyses of religion. In the text cited above, "The Problem of Catholicism in Poland," the fabulation function (called 'myth-making' there) is assessed very critically, or even contrasted with Catholicism. Perhaps experiencing military service at the front and daily contact with death drew Bocheński's attention 
to the natural need for consolation which in such circumstances became so very evident. It is also possible that the reason was more prosaic, namely the preparation of Contemporary European Philosophy. One of the six philosophical currents distinguished by Bocheński in this book is the philosophy of life. Presenting the Bergsonian concept of static religion, Bocheński mentions the role of the fabulation function, calling it a myth-making function. Finally, it could also be the case that Bocheński's deeper interest in this function arose in connection with his sovietological analyses, especially the critical reflection on the concept of religion developed by the communists. This concept in several important points approaches the Bergsonian understanding of static religion as well as the fabulation function. Regardless what prompted Bocheński to pay attention to the fabulation function and static religion, all of his later philosophical analyses of religion would be increasingly focused in that direction.

Concerning the fabulation function, Bergson did not develop this concept alone, but took it from psychologists contemporary to him. In the first half of the twentieth century, it was thought that the fabulation function served the purpose of easing the tensions occurring in the human psyche. Adolf Meyer studied the subconscious self and claimed that it had an inherent capacity or even tendency to resolve psychological conflicts through mental images occurring in states similar to dreams. Theodore Flournoy, a student of Wundt, believed that the function of the mind by which individuals produce images allows not only the disclosure of problems, but also the stimulation of functions other than the verbally-cognitive ones. Pierre Janet called this function mytho-poetic, whereas among German psychologists it was given the name geistiges Auge. Bergson knew these theories and, making use of them, proposed a new and original interpretation of the fabulation function, no longer grounded in psychology, but in philosophy.

In Les deux sources de la morale et de la religion, Bergson writes: "The novel, drama, and mythology together with all that preceded this function, are born of it. But there have not always been novelists or playwrights, while humanity has never been able to do without religion" (Bergson 1993, p. 111). Why do people need static religion? Bergson answers that it is to maintain a counterweight to all the discouraging signals that reach our intelligence from the outside, and above all, to the oft-repeated message that we will die. This message weakens our relationship with life, makes us wonder about the sense of the efforts and the sacrifices made, induces, on the one hand, extreme selfishness and, on the other, utter despair. Life could not afford such a relaxation of the internal tension in people, or distraction of their attention from social requirements. A person discouraged by the inevitability of his own death becomes a social burden, disorganizes group life, and infects others with his defeatism. Thus, the fabulation function saves not only him as an individual but also society. At this point, the social dimension of static religion is clearly visible. It is a religion of a group, tribe, nation, and it is a call for discipline and a source of exclusivity.

Bergson notes that animals do not have this function, since what unites them with life is not intelligence but instinct. "The role played by these images might belong to instinct, and no doubt would belong to it in a being deprived of intelligence" (Bergson 1993, p. 113). According to Bergson, therefore, intelligence has a dual 
role-it reminds man of the inevitability of death, and immediately provides him with images that neutralize this awareness; thus, intelligence deceives itself. These images do not have anything real in them; they are fabulations, fairy tales. "When we lack real experience, falsified experience should be aroused" (Bergson 1993, p. 112). In the further evolution of life, the fabulation function will develop and adopt a variety of new forms. It will be at the root of human activity such as creating images, playing roles, simulating or pretending something. However, at its inception, it only had religious significance. Bergson did not hesitate even to write that "religion alone was the very rationale behind the fabulation function: with respect to religion, this capability would be an effect, not a cause" (Bergson 1993, p. 111). This is, in a nutshell, the matter of the fabulation function.

In Contemporary European Philosophy, Bocheński declares that this function allows people to bear the disappointments that arise when the actions taken by them do not bring the desired results. "For man to be able to endure this bitter knowledge, nature creates gods by using the myth-creating function" (Bocheński 1956, p. 112).

Bocheński once more invoked the fabulation function in his Memoirs. Bocheński briefly recounts there his trip in 1977 to Argentina. He mentions the person of Difunta Corea, a woman "who was to breastfeed her baby long after her death." Bocheński continues: "Chapels, mass pilgrimages, processions. I've seen them myself." And then concludes: "There is no nonsense that could not become a religious superstition. Why? Bergson's claim that man has a fairy-tale-creating function does not explain the depth of this nonsense" (Bocheński 1993b, p. 268).

Apart from direct references, there are also many indirect ones to the fabulation function in Bocheński's texts.

In the selection of texts published in Poland as Lewica, religia, sowietologia [The left, religion, sovietology], written by Bocheński throughout the period during which he directed the Institute of East European Studies in Fribourg, we find among others an accurate description of the communist understanding of religion. "The classical definition of the communists recognizes religion as a fantastic, i.e. a false, picture of, firstly, the forces of nature and social forces constructed in 'people's heads'. Man feels powerless in the face of these forces" (Bocheński 1996, pp. 299-300). Elsewhere we read that the essence of the Marxist view of religion is Marx's saying that "religion is the opium of the people," by which Marx understood the comfort that religion brings to the exploited. Bocheński admits that " $[\mathrm{t}] \mathrm{he}$ meaning of religion as a source of comfort for the exploited is understood correctly inasmuch as a bitterly experienced person will be more easily inclined towards it" (ibid., p. 303). He adds, however, that the communists do not see that man gives in not only to exploitation but also experiences diseases, accidents, unrequited love, failures, death, etc. Bocheński notes that these are all "most common human existential problems." Closing its eyes to them, communism eventually loses sight of the issue of death. In opposition to Marxist beliefs Bocheński presents his own understanding of religion writing that "[r]eligion is primarily-in its essence-an answer to these very problems" (ibid.).

In the short entry under the caption religion in One Hundred Superstitions, a text written in Polish in 1986, Bocheński claims that the centre and the basis of the religious phenomenon is a set of certain ideas called the Creed, whereas religion 
itself fulfils four basic functions. One of them is to provide answers to existential questions such as "the meaning of human life, death and suffering" (Bocheński 1992a, p. 114). Bocheński also mentions the same function of religion while criticizing the superstitions concerning religions purveyed by Marxists. He emphasizes that people adopt a religious attitude not only because they are afraid-as Marxists say-but also for many other reasons, including seeking answers to existential questions.

References to the fabulation function do not exhaust Bocheński's thought on static religion. Of considerable interest in this regard are his writings on the relationship between religion and the nation. In his book entitled Sketches about Polish Nationalism and Catholicism, containing texts from the late 1930s and reissued with minor changes in the early 1990s, Bocheński considers the problem of the relationship between Catholicism and nationalism. He asks what are and should be the specific features given to the universal Catholic religion by individual nations. This specificity is, according to Bocheński, something obvious and its presence in no way diminishes the catholicity of this religion. "A nation has a right to exist, has a duty to defend and grow. Nationalism, unless it contradicts the rights of other nations or exceeds its own powers, is perfectly compatible with the Catholic doctrine, and it is even advocated by it" (Bocheński 1995, p. 58). It is extremely interesting that Bergson says almost exactly the same about static religion in Les deux sources de la morale et de la religion. He states, among other things, that "peace, so far, has always been preparation for defence, or even for attack, in any case for war. Our social duties aim at social cohesion willy-nilly shaping our attitudes to discipline in the face of the enemy" (Bergson 1993, p. 38). It is worth noting that Bergson, wondering about the relationship between the nation and humanity, states that between the nation, whatever its size, and humanity there stands a huge distance, equal to the one between what is finite and what is infinite, between closedness and openness. Those who love their nation in an exclusive way remain on the level of static religion, whereas those who bestow their love on all humankind enjoy the goods of dynamic religion.

Bocheński's texts on national Catholicism are also interesting from another point of view. The beliefs included in them were in sharp contrast to the theories of open Catholicism professed just before the war by many French theologians and philosophers, with Jacques Maritain at the forefront. Bocheński rejected the idea of open Catholicism, with its "mechanistic universalism" emphasizing the lack of differences among people and calling everyone to love everyone. The object of our love, he argued, should be primarily members of the nation. Therefore, what Maritain offers us is "one big misunderstanding." Bocheński noticed that at the basis of Catholicism there lie the open ideals of the French Revolution, liberty, equality, and brotherhood, usually interpreted in the secular spirit, certainly far from traditional Christianity. Now, open Catholicism found inspiration in Bergsonian dynamic religion. It was Bergson who, in the fourth chapter of Les deux sources de la morale et de la religion, openly stated that a democracy based on freedom, equality, and brotherhood is by nature evangelical. These strands were later found in Maritain's program. Bocheński's rejection of the program was significant. In his opinion, the open and trusting Catholicism, reliant on modest and sober means, 
propagated in France had no right to exist in Poland. In this way, Bocheński seemed to stand back from what he had written about dynamic religion in 1932, from the beliefs he held at the time that this kind of religion can be a source of renewal of Catholicism in Poland.

\section{Mysticism and dynamic religion}

From a philosophical point of view, the analyses of dynamic religion in a social context are interesting, but a far greater intellectual challenge was to understand and explain the mysticism located at the heart of religion. A direct experience of God, to whom Bergson devoted so much attention in his Les deux sources de la morale et de la religion, was the main subject of Bocheński's considerations in the texts dealing with dynamic religion.

As I have already mentioned, Bocheński expressed his deep appreciation for dynamic religion and mystics in the quoted letter to his father of 1932. To my knowledge it is the only statement in which he refers enthusiastically to this kind of experience. In his other texts in which he refers to dynamic religion, Bocheński adopts a more neutral or even sceptical attitude towards mysticism. In Contemporary European Philosophy, writing about dynamic religion he notes, admittedly, that the experience of mystics enhances not only the probability of the relevance of the assumptions relating to the beginning of the pulse of life, but also the statement about the existence of God, which cannot be proved on the basis of logic. He also writes that "[ $\mathrm{t}]$ he experience of mystics provides probable, indeed almost certain, grounds for believing in life continuing even after death" (Bocheński 1956, p. 113). This is undoubtedly a positive presentation of dynamic religion, but it seems that Bocheński is here concerned to present Bergson's beliefs, not his own.

In his further texts, in which direct reference is made to mysticism, but indirectly to dynamic religion, Bocheński consistently holds that one cannot say anything certain about the experience of saints and mystics. This is the case in Methods of Contemporary Thought, where using the method of semiotic analysis Bocheński raises the question about what is unspeakable: whether and how to talk about what cannot be expressed in signs available to us. One of the answers, he notes, is Bergson's proposal. "Although what is unspeakable cannot be said, that is, presented and communicated by the signs that have objective reference, it can be made available, to some extent, using a language devoid of objective content" (Bocheński 1992b, p. 59). Bergson believed that intuition cannot be communicated, but another person can be helped to experience it. This experience will certainly not be possible by referring to the signs available to us, i.e. primarily to words, but by evoking some other images, arousing in others the very same or a very similar emotion which they have aroused in a mystic. These images stimulate intuition, according to Bergson the most important power of the knowing mind. For Bocheński this method of learning was minimalist. Giving up thinking and striving to kindle in people a certain emotional state, similar to the state of contemplation of an image or becoming engrossed in music, did not guarantee either the 
communicability, or controllability of this experience. They were thus, in the words of Kazimierz Ajdukiewicz, something irrational.

In a similar way, in the text Wege zum philosophischen Denken, Bocheński examined the issue of the Absolute. He asked what reasons induce people to accept the existence of God. In his response, he distinguished two approaches, i.e. intuitionist and illationist. With regard to the former he cites Bergson. "Intuitionists believe that God, the Absolute, is somehow given directly. It is available to us in our experience" (Bocheński 1986, p. 72). Bocheński immediately noticed that there are very few philosophers who think this way. Besides, even if they actually think like that, "they rarely admit to spreading such theories" (ibid.). Bocheński emphasized that, according to Bergson, this experience is not given to all people, or even to all philosophers, but to mystics only. It is an experience of an exceptional nature.

It seems that Bocheński's key statement explaining the distance he took towards mysticism and dynamic religion is to be found in The Logic of Religion, namely in the chapter in which the philosopher reflects on the possible ways of justifying the basic dogma of religious discourse. He points out that one of the theories that justify this dogma is the theory of confidence. Two situations can be distinguished in this theory. The first is the one in which "[t]he source of revelation was shown only to the prophets through the Scriptures" (Bocheński 1993a, p. 438); the second is the one in which "[t]he source of revelation is shown directly to each of the faithful in such a way that its existence can be easily noticed and the content of revelation is immediately understood by all the faithful" (ibid.). Bocheński notes that in contrast to the former situation, the latter is not at all difficult logically. However, whether we accept it or not depends on actual experience. We may ask ourselves whether there is a continuous, universal and direct communication between the source of revelation and each individual believer. This question, however, must remain unanswered, Bocheński avers, because we do not have access to this kind of empirical data. Logic alone is not able to determine whether such a statement is true or not, because the experience that we are talking about here is not mediated in a language; it is extra-notional. We should add at this point that it could be that all the faithful participate intuitively in a direct revelation by the Absolute of the religious truth, without knowing this. In that case mystics would differ from other believers not because they have a special experience, but because they become aware of it. Many other peculiar situations would also be conceivable. Bocheński, however, did not leave the reader in the dark as to his own beliefs on the theory of direct revelation. "Personally, the author is convinced that the theory is wrong for reasons of an empirical character" (Bocheński 1993a, p. 439). As a matter of fact, common experience teaches us that the faithful obtain access to the basic dogma not directly, but indirectly, through the text of the Scripture and the Creed. "The faithful are not in contact with God himself, unless they belong to a small group of pious women and men called, on the grounds of RD [religious discourse-PK], 'mystics"'(ibid.). Hence, even if we acknowledge the fact that these special people, privileged souls, as Bergson spoke about them, have an intuitive insight into God, experience Him in a direct way, for example hearing His words, requests or orders, then what they experience and what they say about the experience is totally incomprehensible to us. When we read their texts, our situation will be similar to those people who not 
having absolute pitch want nevertheless to experience the essence of the music by reading a score of a concerto or symphony.

In the light of this passage it is easier to understand Bocheński's distance from dynamic religion and mysticism. Bocheński believed that this concept can be regarded as a theory of justification of the basic dogma of religion, but such reasoning would be extremely exclusivist: it could be applied only to individuals, leaving outside its scope the countless faithful who have never experienced direct contact with God. Their experience is quite different: it is the experience of religious practices of worship and obedience to a common authority representing God understood in the same way. The religion that they experience is social, and thus perceptible and possible to describe. It is not a dynamic religion, but a static one.

In a similar way, Bocheński referred to dynamic religion in One Hundred Superstitions. In the entry religion he states that religious emotionalism, which argues that "religion is only a collection of feelings," is a superstition and a manifestation of reductionism (Bocheński 1992a, p. 115). This is an example of reducing religion to only one of its components. This superstition offends religious people, because there is no religion "without a creed, i.e. without some propositions." There is no religion that would be only a collection of feelings. Certainly, we must remember that Bergson believed that in social life there is no such purely emotional religion, that even the most impenetrable mystical experience seeks some rational means. However, rationalization will always be secondary to the emotional surge, unable by itself to draw anyone towards God. Bocheński, on the contrary, believed that for the majority of religious people, this kind of rational formula is sufficient.

\section{Summary}

As we have seen, Bocheński regularly returned to the Bergsonian philosophy of religion. First of all, he highlighted those strands in it that referred to static religion, i.e. to the social dimension of religion. He drew attention to the fabulation function of intelligence, which is responsible for creating false images whose aim was to maintain people's close ties with life. This bond is essential for the normal survival of society. Bochenski treated with scepticism those strands in Bergson's philosophy of religion, which are associated with dynamic religion, particularly mysticism; about such experiences no one can say anything for certain. Even if there are some people who experience religion in a direct way, then we should not expect others to trust such an experience uncritically. For the good of society, we cannot even expect them to do so. In this way, Bocheński argued for a naturalist interpretation of religion against the spiritualist one. He did not share many Catholic thinkers' enthusiasm for dynamic religion, rather emphasizing the importance of static religion. This is surprising, since static religion, as presented by Bergson, in many ways resembles the product of false consciousness and consequently is exposed to the danger of reductionism. Bocheński apparently concluded that this case is less of a threat to religion than depriving religion of any intellectual content. 
I would like to finish my text with a personal reminiscence. In August 1994 I visited Józef Bocheński in Fribourg. During the meeting, I presented him with a Polish translation of Les deux sources de la morale et de la religion, Henri Bergson's last book, which I had co-translated and which had been published a year earlier. Bocheński accepted the book with satisfaction while saying a few warm words about Bergson and his philosophy. He spoke, among other things, about what, according to him, we should appreciate Bergson for. To my surprise, it was not the concept of dynamic religion, but the concept of the fabulation function. Bocheński's unexpected statement induced me many years later to look at his texts on religion in the light of the Bergsonian analyses of religion. Hence, the subject of the foregoing remarks.

Open Access This article is distributed under the terms of the Creative Commons Attribution License which permits any use, distribution, and reproduction in any medium, provided the original author(s) and the source are credited.

\section{References}

Bergson, H. (1993). Dwa źródta moralności i religii [The two sources of morality and religion]. Kraków, Poland.

Bocheński, J. M. (1932). Problem katolicyzmu w Polsce [The problem of catholicism in Poland], "Droga", 9, 1932, pp. 773-785 (under the pseudonym of Jan Ursyn).

Bocheński, J. M. (1956). Contemporary European philosophy. Berkeley, USA: University of California. Bocheński, J. M. (1986). Ки filozoficznemu myśleniu [Towards philosophical thinking]. Warszawa, Poland. [Originally published as Wege zum philosophischen Denken. Basel-Freiburg-Wien: Herder, 1959].

Bocheński, J. M. (1992a). Sto zabobonów [One hundred superstitions], Kraków, Poland.

Bocheński, J. M. (1992b). Wspótczesne metody myślenia [Methods of contemporary thought]. Poznań, Poland.

Bocheński, J. M. (1993a). Logika i filozofia. Wybór pism [Logic and philosophy. Selected writings]. Warszawa, Poland.

Bocheński, J. M. (1993b). Wspomnienia [Memoirs]. Kraków, Poland.

Bocheński, J.M. (1995). Szkice o nacjonalizmie i katolicyzmie polskim [Sketches of Polish nationalism and catholicism]. Kraków, Poland.

Bocheński, J. M. (1996). Lewica, religia, sowietologia [The left, religion, sovietology]. Warszawa, Poland.

Bocheński, J. M. (2008). Listy do ojca. Prywatna korespondencja [Letters to my father. Private correspondence]. Kraków, Poland.

Borzym, S. (1984). Bergson a przemiany światopogladowe w Polsce [Bergson and the ideological transformation in Poland]. Wrocław, Poland.

Kostyło, P. (2007). Ja jestem, który się staję. Henri Bergson wobec problemu Boga, [in:] Od filozofii refleksji do hermeneutyki. Francuska filozofia religii [I am who I am becoming. Henri Bergson and the problem of God, [in:] From reflection to hermeneutic philosophy. The French philosophy of religion]. Barcik, J. (Ed.), Kraków, Poland.

Pouivet, R. (2009). Jan Salamucha's analytical thomism. In Lapointe, S., Woleński, J., Marion, M., Miskiewicz, V. (Eds.) The golden age of Polish philosophy. Kazimierz Twardowski's philosophical legacy. New York, USA.

Skoczyński, J., \& Woleński, J. (2010). Historia filozofii polskiej [A history of Polish philosophy]. Kraków, Poland. 